KATIE HOSELTON is a 4th year Political Science major with a concentration in Global Politics. After graduation in June, Katie plans to travel and work abroad, before applying for graduate school. She is passionate about international law and human rights, and is currently working to make Cal Poly a conflict mineral-free campus, in an effort to divest from companies that support the conflict in the Democratic Republic of Congo. She loves big dogs and strong margaritas, and dreams of the day when Hilary is president and when the IMF actually gives more than it takes. She hopes to work for an international institution and change the current system of foreign aid, all while having a large family of adopted children and dogs. 


\section{THE TRAGEDY OF TEXTILES: EXPLORING THE ACTORS RESPONSIBLE FOR THE EXPLOITATION OF WORKERS IN THE GLOBAL GARMENT INDUSTRY}

Katie Hoselton

\section{Introduction}

On April 24, 2013 the world witnessed the worst accident in the history of the garment industry, when an eight-story factory collapsed in Bangladesh. Over the course of the following two weeks, the death toll rose to over 1,100 people, as more bodies were found in the rubble. The New York Times reported that the building previously had been deemed unsafe for occupation due to multiple cracks in its infrastructure, however the building owner, Sohel Rana, ignored these warnings and continued operation without making any amends. ${ }^{85}$ The Washington Post reported that the building was constructed on swamp land, making the area unstable for tall structures. ${ }^{86}$ The original building plan had been approved to be five-stories; however, reports say that the owner illegally

${ }^{85}$ Julfikar Ali Manik and Jim Yardley, "Scores Dead in Bangladesh Building Collapse," The New York Times, April 24, 2013, sec. World / Asia Pacific.

${ }^{86}$ Associated Press, "Bangladesh Probe Faults Swampy Land, Poor Building Materials, Heavy Equipment for Collapse," The Washington Post, May 22, 2013. 
added on three stories so that he could rent the space out to more companies. The heavy weight of the machinery required for garment production, combined with the additional stories and the unstable foundation of the building are all factors that contributed to the collapse. ${ }^{87}$ It was noted that cracks in the structure's walls caused authorities to deem the building unsafe for inhabiting the day before the collapse, however the owner required all workers to report to work the next day, not wanting to lose any time that could be spent manufacturing. Five different companies, including Tommy Hilfiger and Calvin Klein, operated in this eight-story factory, causing extreme overcrowding and pushing the weight of the building far past its capacity. ${ }^{88}$ Workers in the former Rana Plaza factory in Bangladesh work for $\$ 38$ a month, which is purportedly a standard, but nearly unlivable, wage for workers in the region. ${ }^{89}$

Sadly, the exploitation of workers in the garment industry is nothing new to the international arena. The early 1990's brought the notion of sweatshops to the public eye, through multiple media exposés of large Western corporations. ${ }^{90}$ In 1995, Nike admitted to "serious breaches" of its labor standards, as the media exposed its rampant use of child labor and overcrowded, underpaid sweatshops. ${ }^{91}$ Nike founder and CEO Phillip Knight confessed in 1998 that, Nike products have "become synonymous with slave wages, forced overtime, and arbitrary abuse," which is the first step to solving the problem. ${ }^{92}$ Since this exposure, Nike has made adjustments in their labor practices such as revamping their code of conduct and reimbursing workers; however, many groups are skeptical that their policy changes have actually improved conditions for workers. ${ }^{93}$ Oxfam and The Clean Clothes Campaign, an organization dedicated to improving the working conditions of garment workers, were "not convinced" 94 by a sustainability report published by Nike in 2001, noting that Nike's efforts "haven't

87 Ibid

${ }^{88}$ Associated Press, "Bangladesh Probe Faults Swampy Land, Poor Building Materials, Heavy Equipment for Collapse," The Washington Post, May 22, 2013.

${ }^{89}$ Ibid

90 "Sweatshops," International Labor Rights Forum. 2012. (Accessed May 13, 2013).

91 Janelle McCalla, "Global Reputation," https://sites.google.com/a/email.vccs.edu/ bus $100 \mathrm{jmccalla} /$ home/global-reputation-2.

${ }_{92}$ Ibid

${ }^{93}$ Ibid

${ }^{4}$ Steve Boggan, "Nike Admits to Mistakes Over Child Labor," The Independent UK, October 20, 2001. 
ended abuses across the hundreds of factories that produce its goods." ${ }^{95}$ Let it be noted however, that Nike is by no means the only culprit of garment worker exploitation; NGOs have confirmed that Walmart also has a "long history of high-profile labor rights violations," and while it has instituted reforms over the years, the International Labor Rights Forum has noted that their inspections "are still overwhelmingly pre-announced and, partially as a result, ineffective". ${ }^{96}$

Exploitation of workers in the garment industry is also not limited to individuals in developing countries. In 1996, President Clinton gave a speech in which he acknowledged that over seventy workers in a factory in El Monte, California had been working "in virtual slavery behind barbed wire in a garment factory." ${ }^{97}$ In response to this, the California Senate passed one of the most comprehensive anti-sweatshop laws in history, Assembly Bill 633. Known as the "sweatshop reform bill", the legislation provides California garment workers with minimum wage standards and protection under the law. ${ }^{98}$ However, the same protections cannot be said for workers in other nations. It is clear that the recent collapse in Bangladesh is not unprecedented but is rather another incident in a long pattern of tragedies in the garment industry. While history shows that corporations have made efforts to improve their standards, it appears as though the changes made have lacked teeth, as this vulnerable population of garment workers continues to be exploited. As the companies involved in the Bangladesh crisis scramble to clear their image by proposing international agreements and writing checks to support safety programs, it will become clear in the weeks and months to come whether these efforts will institute any tangible reforms, or whether they will simply be like the rest of the labor laws in the garment industry: toothless and ineffective.

The recent incidents in the garment industry, namely in Bangladesh and Cambodia, combined with the grim history of labor law enforcement, implies that the state of the garment industry is neither improving, nor remaining stagnant; conditions for workers are actually deteriorating. This presents a rather

${ }^{95}$ Eugenia Levenson, "Citizen Nike," CNN Money, November 17, 2013.

96 "Wal-Mart Campaign," International Labor Rights Forum, 2012, (Accessed May 22, 2013).

${ }_{97}$ William J. Clinton, "Remarks Announcing Measures to Improve Working Conditions in the Apparel Industry and an Exchange with Reporters," (speech, U.S. Congress, Washington DC, August 2, 1996), The American Presidency Project.

${ }^{98}$ Lora Jo Foo and Julie A. Su, "Let the Sweatshop Reform Law Work," The Los Angeles Times, April 7, 2000. 
troubling scenario: how is it that globalization has improved so many aspects of people's lives, from medicines to technological inventions, yet the lives of those producing the goods are getting so much worse? Clearly something is missing in the efforts that have been made to uphold human rights in this industry. The question is, where are these shortcomings occurring? The nonprofit investigative group, CorpWatch, attributes the widespread exploitation of garment industry workers to intense global capitalist system, which forces companies to market goods for the lowest price possible. ${ }^{99}$ This quest for the lowest sticker price can be traced back to the place where the goods are made; it is the factory workers that bear the largest burden of this system, as their wages are slashed to absolute minimums. CorpWatch notes that this slashing of prices is fed by " brutal competition from the mass-merchandise discounters," trapping retailers in a "Darwinian battle for survival." 100 This race to the bottom will not cease unless a drastic change is made at one of three levels: international organizations, Western corporations, or consumers. CorpWatch claims that the conditions of garment workers will not change "as long as global commodity chains continue to [...] satisfy the needs of powerful transnational corporations." ${ }^{101}$ We, as consumers, have built a system of trade that is based on a foundation of exploitation, which leads us, as members of the international community, to ask the question: Why does the garment industry exist without minimal labor protections, leaving workers extremely vulnerable to exploitation?

\section{Conventional Wisdom}

One might think that the United States, as a prominent upholder of human rights, would oppose trade agreements that condone sweatshop labor; however, partisan polling data suggests otherwise. Americans generally favor all policies that promote international trade, throwing caution to the wind when it comes to labor standards. A Gallup poll from February 2013 found that fifty-seven percent of Americans view foreign trade as an opportunity for economic growth, rather than a financial threat. ${ }^{102}$ A poll conducted by the Pew Research Center

99 Hector Figueroa, "In the Name of Fashion: Exploitation in the Garment Industry," CorpWatch, January 1, 1996. (Accessed May 26, 2013).

${ }^{100}$ Ibid

${ }^{101}$ Ibid

102 Jeffrey M. Jones, “Americans Shift to More Positive View of Foreign Trade," Public Opinion Polling, Gallup Economy, February 28, 2013. (Accessed May 20, 2013). 
in 2009 found that the percent of Americans who feel that international trade is good increased twelve percentage points from 2008. ${ }^{103}$ Despite the massive global economic recession of 2008, the poll shows that Americans feel that engaging in trade of all forms is beneficial to the U.S. economy. The Pew Research Global Attitudes Project also found in a recent poll that Americans feel that international trade not only benefits the U.S., but also boosts foreign economies. The poll published on May 23, 2013 cited this American belief that developing countries involved in the manufacturing side of goods production also benefit from trade agreements. Pew found that fifty-four percent of Americans think that trade is beneficial for citizens of developing countries, compared to only nine percent which disagree. ${ }^{104}$ Pew holds that in general, "the U.S. business community has supported trade agreements." 105

Interestingly, the same Pew poll found that Americans are concerned about the threat of inflation: fifty-one percent felt that "rising prices are a very big problem." 106 This concern about rising prices helps to explain the exploitative actions of companies who seek to compete in the global capitalist market. Despite this concern, the majority of the countries surveyed in the Pew 2009 poll believe that "the free market approach to economics is good for society, even if it produces income inequalities." 107 From this belief it can be inferred that most Americans feel that globalization and international trade agreements are ultimately beneficial to all parties involved. This perception is wrong because recent events have shown that all parties involved in trade do not benefit equally. In contrast, workers on the manufacturing end of commodity production benefit substantially less than those on the corporate side, and in fact are exploited to the extent that their basic human rights are violated. The conventional wisdom

${ }^{103}$ Pew Research Center, "Confidence in Obama Lifts U.S. Image Around the World," Public Opinion Polling, Pew Global Attitudes Project, July 23, 2009. (Accessed May 22, 2013).

${ }^{104}$ Pew Research Center, "Economies of Emerging Markets Better Rated During Difficult Times," Public Opinion Polling, Pew Global Attitudes Project, May 23, 2013. (Accessed May 23, 2013).

105 William H. Cooper, "The Future of U.S. Trade Policy: An Analysis of Issues and Options for the 112th Congress," CRS Report R41145, Washington DC, Congressional Research Service, January 4, 2011. (Accessed June 1, 2013).

${ }^{106}$ William H. Cooper, "The Future of U.S. Trade Policy: An Analysis of Issues and Options for the 112th Congress," CRS Report R41145, Washington DC, Congressional Research Service, January 4, 2011. (Accessed June 1, 2013).

${ }^{107}$ Pew Research Center, "Confidence in Obama Lifts U.S. Image Around the World," Public Opinion Polling, Pew Global Attitudes Project, July 23, 2009. (Accessed May 22, 2013). 
is also incorrect because it assumes that Americans are generally unaware of the horrific working conditions that many laborers in the manufacturing industry are subjected to, which explains why Americans believe that trade is mutually beneficial. In reality, many Americans are aware of the degree and extent of exploitation that occurs in developing countries and still think that trade should be pursued and prices should be driven lower. Americans generally feel that even though sweatshops often commit rampant human rights violations, cheap labor is essential to keep prices low, and is thus the best of a series of bad options. Pew polling data shows that Americans favor free trade and globalization and sadly, the basic rights of workers in developing nations is simply not an issue of primary concern to them.

\section{Methodology and Primary Evidence}

In order to understand how a crisis as deadly as the recent Bangladesh collapse can occur in this day and age, this paper will use quantitative methodology to investigate which actor has the most influence on the garment industry. This paper will draw data from primary sources, including but not limited to CRS Reports, ILO reports, Presidential speeches, and non partisan polling data. This research will be supplemented by data from secondary sources, employing scholarly journals, such as JSTOR, as well as articles from university publications, and noteworthy newspapers like The New York Times and The Washington Post. This paper will employ three different case studies, as well as the theoretical paradigm of Marxism, to examine the issue from variant perspectives. It will examine international institutions, multinational corporations, and consumers, to see the role that each plays in the garment industry.

\section{Theoretical Paradigm}

My research suggests that the best paradigm to frame and explain my findings is the structural framework of Marxism as it pertains to international relations. Based off of the teachings of Karl Marx and Friedrich Engels, Marxism looks to class-rankings, social systems, and the international division of labor to explain state behavior. ${ }^{108}$ It takes a material approach to historical development, to show how trade, economics, and capitalism have framed the current

108 “Marxism: International Relations Theory in Brief," Bukisa, August 15, 2010. 
international system. ${ }^{109}$ While Marxism is a structural as opposed to an ideological theory, it can provide insight on many of the historical behaviors of states in international relations. ${ }^{110}$ Its key implication is that material forces drive the behavior of actors in the international arena, as opposed to abstract factors like power, sovereignty, and norms. ${ }^{111}$ Gareth Dale, a senior professor at Brunel University, holds that a society's "mode of production" is the "key to understanding its systems of power and belief." ${ }^{112}$ Marxism views state behavior from a context of capital, production, trade, and industry, which provides an insightful framework to view the issue at hand. ${ }^{113}$

While Marxism works well to explain my second case study of multinational corporations, it does not shed much light on the first case study of international institutions. Marxism barely even recognizes the existence non-state actors, and makes almost no reference to international law; B.S. Chimni of the Center for Studies in Diplomacy in New Delhi notes that the founders of Marxism "never directly address the subject." ${ }^{114}$ As a result, scholars are left to apply the tenets of Marxist methodology to international institutions and not-state actors, in hopes of viewing the rest of the behaviors of international actors through Marxist eyes. In doing so, scholars postulate that within the Marxist framework, international institutions are actors with limited power, but influence none the less. ${ }^{115}$ Because they serve the interests of groups, as opposed to the national interests of states (a concept which Marxism discredits), we can infer that Marxism gives international institutions some viable credit as an actor. However, since they are driven by interests rather than capital or production, they are not the most influential or dominating actor. Chimni posits from the

${ }^{109}$ David McLellan and Sidney Hook, "Marx: The First Hundred Years; Marxism and Beyond," Foreign Affairs, 1983.

${ }^{110}$ Alexander Anievas, “Marxism and World Politics: Contesting Global Capitalism," London: Routledge, 2010.

${ }^{111}$ Ibid

112 Gareth Dale, "Marxism," Oxford Bibliographies, March 2, 2011, (Accessed June 2, 2013).

${ }^{113}$ Alexandre Kirchberger, "Marx, Ideology, and International Relations," University of Sussex, (Accessed June 4, 2013).

${ }^{114}$ B.S. Chimni, "Marxism and International Law: A Contemporary Analysis," Center for Studies in Diplomacy, International Law, and Economics. School of International Studies Jawaharlal Nehru University, New Delhi. (Accessed June 8, 2013).

${ }^{115}$ Ibid 
works of Marxism that international institutions are viewed "as a device which serves sectional global interests," but not any other actor in particular. ${ }^{116}$

In contrast, Marxism frames my second and third case studies, of multinational corporations and consumers very well. Marxism supports the idea that workers are being exploited because of the race to the bottom mentality felt by multinational corporations in the aggressive capitalist market. ${ }^{117}$ A Marxist would see the rampant exploitation of garment workers as a consequence of corporate greed, driven by the high demand of consumers. This fierce competition drives corporations to seek the lowest wage possible, causing many to ignore the flimsy standards put in place in hopes of gaining an edge on the prices of their competitors. ${ }^{118}$

\section{Research Findings}

\section{Case Study: International Institutions}

The most obvious culprit and often the first to be blamed for crises like the recent collapse in Bangladesh are international institutions such as the International Labor Organization (ILO) and the United Nations (UN). For the purposes of this paper, I will examine only the ILO as a representative of international institutions, since it is designed primarily to tackle the topic of interest. The ILO can set forth labor standards in the form of either conventions or recommendations. ${ }^{119}$ Conventions are legally binding contracts to all states that are members of the ILO and choose to ratify it. ${ }^{120}$ Recommendations are non-binding and merely set forth suggestions often regarding how to implement certain aspects of a convention. ${ }^{121}$ The ILO meets once a year to draft and update conventions and ratifications, and if asked by a member state for

${ }^{116}$ B.S. Chimni, "Marxism and International Law: A Contemporary Analysis," Center for Studies in Diplomacy, International Law, and Economics. School of International Studies Jawaharlal Nehru University, New Delhi. csssjnu.tripod.com/marx.html (Accessed June 8, 2013).

117 Bill Dunn, "Global Political Economy: A Marxist Critique” London: Pluto, 2009.

${ }^{118}$ Alexander Anievas, "Marxism and World Politics: Contesting Global Capitalism," London: Routledge, 2010.

${ }^{119}$ International Labor Organization, "Applying and promoting international labor standards," 2013, (Accessed June 8, 2013).

${ }^{120}$ Ibid

${ }^{121}$ Ibid 
technical assistance during the year, the ILO will gladly abide. ${ }^{122}$ The labor standards set forth by the ILO are backed by supervisory system, which conducts periodic inspections to ensure that states are adequately abiding by the conventions they ratify. If it is found that the standards are being breached, the ILO can make further recommendations, or "assist countries through social dialogue and technical assistance." ${ }^{23}$ It also allows any worker or employer organization to file a complaint if they believe that an aspect of a convention is being violated. ${ }^{124}$

But this, many argue, is where the authority of the ILO ends. Like the UN, and other international institutions, the ILO has only as much power as its members allow it to have, which is usually not very much. The ILO has set forth eight fundamental conventions, covering all aspects of labor from minimum age to forced labor, and hoped to receive universal ratification on these eight crucial documents, but today still only $83 \%$ of the total possible states have signed on. ${ }^{125}$ While this may seem like a high percentage, the implication of this is that there are roughly thirty nations that have not agreed to international labor standards and therefore legally do not need to comply. The ILO is fully aware of the rampant violations of labor laws in countries around the world, as seen in their emphasis in problematic regions discussed later in this paper; many argue that they lack the authority to do anything about it. Nazia Habib-Mintz of the Journal of International Business and Economy frees the World Trade Organization (WTO) of any blame by noting that the task of developing and promoting labor standards was delegated to the ILO in 1996. ${ }^{126}$ She notes the "toothless" aspect of the organization's enforcement power, when saying that the ILO merely "urges nations to honor their obligation," to meet the

122 “The ILO to the Rescue?," Institute for International Economics, pp.93-109, (Accessed June 7, 2013).

${ }^{123}$ International Labor Organization, "Applying and promoting international labor standards," 2013, (Accessed June 8, 2013).

124 “The ILO to the Rescue?," Institute for International Economics, pp.93-109, (Accessed June 7,2013$)$.

125 International Labor Organization, "Conventions and Recommendations," 2013, (Accessed June 8, 2013).

${ }^{126}$ World Trade Organization, "Core Labor Standards," Singapore Ministerial Declaration, April 2007. 
standards that they agreed to in a convention. ${ }^{127}$ She implies that this honors system approach to enforcing labor standards does not provide enough of an incentive for countries to abide by when big businesses with copious capital to invest are mixed into the equation.

In contrast, Kimberly Ann Elliot from the Institute for International Economics makes the case that the ILO does indeed have teeth, arguing that it "is the competent body to set and enforce labor standards in general and should be given the support necessary to do the job." ${ }^{128}$ She holds that the ILO has three tools available to it for the purpose of law and norm enforcement: regular reporting and review processes, the ability to provide technical assistance, and avenues to raise issues of noncompliance; she refers to these tools colloquially as sunshine, carrots, and sticks. ${ }^{129}$ Another scholar from the International Institute for Economics agrees with this argument, noting that "the ILO has extensive mechanisms for supervising the application of its labor conventions." ${ }^{130}$ This scholar points to numerous examples of the tangible and significant reforms the ILO was able to make when provided with sufficient funding. ${ }^{131}$ Elliot cites the example of Burma in 1996, when delegates filed a complaint that Burmese factories were tolerating forced labor, employing the "sticks" tool of the ILO. ${ }^{132}$ The report was processed and the ILO was eventually able to cut off technical assistance to the region, ban Burma from its meetings, and call upon member states to impose sanctions on the country. ${ }^{133}$ These actions were enough to get Burma to cooperate to some degree, marking a huge success for the ILO and for diplomacy in general. ${ }^{134}$ In this case, the mere threat of sanctions was enough to convince Burma to change its ways, but whether the sunshine and carrots approach is enough to convince other nations to move, is the question

${ }^{127}$ Nazia Habib-Mintz, "Multinational Corporations' Role in Improving Labour Standards in Developing Countries,"Journal of International Business and Economy, April 4, 2009.

${ }^{128}$ Kimberly Ann Elliot, "The ILO and Enforcement of Core Labor Standards,” International Economy Policy Briefs, Institute for International Economics, July 2000 (Accessed June 10, 2013).

${ }^{129} \mathrm{Ibid}$

130 "The ILO to the Rescue?," Institute for International Economics, pp.93-109, I(Accessed June 7,2013$)$.

${ }^{131}$ Ibid

132 Kimberly Ann Elliot, "The ILO and Enforcement of Core Labor Standards,” International Economy Policy Briefs, Institute for International Economics, July 2000 (Accessed June 10, 2013).

${ }^{133}$ Ibid

134 “The ILO to the Rescue?," Institute for International Economics, pp.93-109, (Accessed June 7,2013$)$. 
we are left with. Elliot says that "the real test of ILO credibility, however, will come over time as we see whether Burma is a precedent or an aberration." 135 Other successes of the ILO have been documented and debated by scholars. A project instigated by the ILO in 2001 called Better Factories Cambodia supposedly made so much progress in improving working conditions in the region, that it served as the model for the creation of the ILO's Better Work Program. ${ }^{136}$ This program, created in 2012 is supported by the International Finance Corporation and seeks to promote the implementation of safe labor practices in seven developing countries. ${ }^{137}$

After hearing both sides of the debate over the effectiveness of the ILO, we are left to conclude on its ability and responsibility as an international actor to regulate and enforce labor standards in the garment industry. There is indisputable evidence that the ILO does indeed have enforcement powers, and it has been cited that the combination of its carrots, sticks, and sunshine have produced desirable results. However the question of whether the "sticks" of the ILO are truly strong enough to enforce the range and realm of its conventions, still looms. It is important to keep in mind that the ILO is not an international police but rather an institution comprised of willing members; it is this distinction that is both the greatest attribute and detriment to an organization of this kind. The ILO serves the important function of creating and maintaining global norms, that for the most part, reflect the ideas of the international community . International institutions have predominately defined our concepts of right and wrong regarding international markets, and determined what is acceptable completely unacceptable in today's world, most of which transcend all cultural and geographic boundaries. And, while it has been proven that the ILO does have influence over the labor conditions of workers in the garment industry, in a world driven by capitalism and material gains, international institutions are not the actors with the most influence on the enforcement of labor standards.

\section{Case Study: Multinational Corporations}

Another group of actors that have undeniable influence in the garment industry are multinational corporations (MNCs), to which some scholars claim, "are a

${ }^{135}$ Kimberly Ann Elliot, “The ILO and Enforcement of Core Labor Standards," International Economy Policy Briefs, Institute for International Economics, July 2000, (Accessed June 10, 2013).

136 “ILO/IFC Partnership," Better Work, International Labor Office, 2012, http://betterwork. org/global/?page_id=304 .

${ }_{137}$ Ibid 
powerful economic force." ${ }^{138}$ Adhering perfectly to Marxist theory, G. Gereffi of the Journal of International Economics argues that MNCs are the driving force in "the whole supply chain," and use their penetrative force to "ensure productivity, efficiency, and reliability of performance." ${ }^{139}$ This posits that MNCs, as the possessors of capital and global resources, are one of the most dominating actors in the international arena. However, ethical concerns that arose when corporations began moving overseas for cheap labor have caused some scholars to believe that apparel manufacturers are currently "in a squeeze," or struggling financially. ${ }^{140}$ MNCs have huge incentives to violate labor standards, and are able to do so as a result of a lack of law enforcement which is in turn "due to institutional and infrastructural limitations". ${ }^{141}$ Dexter Roberts, a Businessweek reporter, notes that it is fairly easy to violate labor laws and get away with it; a Businessweek investigation found that "numerous Chinese factories keep double sets of books to fool auditors and distribute scripts for employees to recite if they are questioned." ${ }^{142}$ Gereffi says that because foreign manufacturers can produce goods that are similar in quality but much cheaper in cost, the question for most MNCs today "is no longer whether to engage in foreign production, but how to organize and manage it," implying that the use of foreign labor by MNCs is inevitable. ${ }^{143}$

The effects of the extremely competitive capitalist market have triggered what scholars are calling a "race to the bottom," which is an aggressive quest to produce goods at the lowest cost possible. ${ }^{144}$ Evidently, this starts with the production of the raw materials which occurs in the textile and apparel sectors of the garment industry, and directly affects the wages of the manufacturers

138 A. Chandler Jr., and B. Mazlish, "Leviathans: Multinational Corporations and the New Global History," Cambridge: Cambridge University Press. 2005.

139 G. Gereffi, "International Trade and Industrial Upgrading in the Apparel Commodity Chain," Journal of International Economics 1999.

${ }^{140} \mathrm{Ibid}$

${ }^{141}$ Nazia Habib-Mintz, "Multinational Corporations' Role in Improving Labour Standards in Developing Countries,"Journal of International Business and Economy, April 4, 2009.

${ }^{142}$ Dexter Roberts and Pete Engardio, "Secrets, Lies, and Sweatshops," Bloomberg Businessweek Magazine, November 26, 2006.

${ }^{143}$ G. Gereffi, "International Trade and Industrial Upgrading in the Apparel Commodity Chain,” Journal of International Economics 1999.

${ }^{144}$ Nazia Habib-Mintz, "Multinational Corporations' Role in Improving Labour Standards in Developing Countries,"Journal of International Business and Economy, April 4, 2009. 
in these regions. The NGO CorpWatch identifies one cause of this race to the bottomas wage deflation. ${ }^{145}$ Hector Figueroa, a journalist for the North American Congress of Latin America, reported that the prices of retail clothes in the U.S. are not increasing quickly enough to keep up with inflation, and as a result, "average profit margins for apparel manufacturers are around 2 percent below manufacturing as a whole." 146 Further exacerbating this effect are "declining average wages" in U.S. household incomes, "increasing income inequality," and "brutal competition from the mass-merchandise discounters." 147 The consequence is that MNCs today are "caught in a Darwinian battle for survival," and when push comes to shove, it is the vulnerable workers who will feel the burn of these effects.

These findings present the question: do MNCs have the power to improve the working conditions of laborers in the garment industry? Nazia Habib-Mintz of the Journal of International Business and Economy holds that the motivations of MNCs "are complexly tied with labour standards and its practice," implying that MNCs do have a significant hold on the industry. ${ }^{148}$ She also notes that the labor supply in developing countries is "inelastic," or fixed, causing wages to decline over time, and giving MNCs "more bargaining power over wages and choices." ${ }^{149}$ Scholars from the University of Colorado, Boulder argue that MNCs are left to compete "on the basis of one of the few factors of production they control: the cost of labor." 150

All of these factors show that MNCs have a direct influence on the wages and working conditions of laborers in developing countries. The fact that MNCs can chose to "turn a blind eye to labor standards irregularities," "ignore set minimum wages," and "coerce labor to work over 100 hours per week in

${ }^{145}$ Hector Figueroa, "In the Name of Fashion: Exploitation in the Garment Industry," CorpWatch, January 1, 1996. (Accessed May 26, 2013).

${ }^{146}$ Ibid

${ }^{147}$ Ibid

${ }^{148}$ Nazia Habib-Mintz, “Multinational Corporations' Role in Improving Labour Standards in Developing Countries,”Journal of International Business and Economy, April 4, 2009.

${ }^{149}$ D. Rodrik, "Has Globalization Gone Too Far," Washington: Institution for International Economics, 1997.

${ }^{150}$ Mark Anner, Jennifer Bair, and Jeremy Blasi, "Buyer Power, Pricing Practices, and Labor Outcomes in Global Supply Chains”. Institute of Behavioral Science. University of Colorado, Boulder. August, 2012. 
unhealthy environments," shows that they also have the power to revoke these practices and implement humane ones. ${ }^{151}$

However, because of the capital-driven market system, MNC's decision of whether or not to uphold human rights hinges on consumer demand. If Marxism is the lens through which this issue is best viewed, the dominating actors are "big business[es]," which will respond to one thing only: capital. The instant consumers begin to demand products that have been manufactured ethically and responsibly, MNCs will respond. This was seen with Nike in the 1990s, after multiple media outlets exposed the company's use of child labor and domestic servitude in its Asian factories. ${ }^{152}$ In response to the national outcry and opposition of consumers, Nike admitted to its mistakes, and supposedly reimbursed its workers and tightened its regulations and inspection techniques. ${ }^{153}$ While it's unclear whether Nike's reforms have actually improved the conditions of their workers, this example gives support to the idea that MNCs will respond to consumer demand, and that they do have a strong influence over worker conditions. CorpWatch sums up the state of the industry fairly well: "As long as global commodity chains continue to discipline and direct the region's economies to satisfy the needs of powerful transnational corporations, the working conditions of people throughout the hemisphere are not likely to improve." 154

\section{Case Study: Consumers}

Consumers are one of the most overlooked but important actors that have a huge influence over the entire global supply chain. Scholars from the University of Boulder, Colorado argue that the role that consumers play in the global market is often disregarded, holding that any attempt to improve sweatshop conditions for workers "must recognize that the dynamics of the buyer-driven apparel chain result in systematic cost pressures on suppliers that are conducive

${ }^{151}$ Q. Tahmina, “Labour-Bangladesh: Garment Exports Thrive on Dirt," Inter Press Service News Agency. April, 2007, (Accessed June 6, 2013).

152 “Sweatshops," International Labor Rights Forum. 2012. (Accessed May 28, 2013).

153 Janelle McCalla, “Global Reputation,"https://sites.google.com/a/email.vccs.edu/bus100jmccalla/home/global-reputation-2 (Accessed May 28, 2013).

154 Hector Figueroa, "In the Name of Fashion: Exploitation in the Garment Industry," CorpWatch, January 1, 1996. http://www.corpwatch.org/article.php?id=3034 (Accessed May 26, 2013). 
to violations of workers' rights." 155 The effect that consumers have is undeniably significant, but indirect; consumers do not have access to the factories themselves, but their actions directly affect those who do. Many scholars argue that this increase in political activism by consumers and human rights groups "has focused greater scrutiny on the behavior of exporting firms and large multinationals." 156 Steven Greenhouse of The New York Times reported that after the collapse in Bangladesh, companies rushed to clear their names of all connections to the crisis: "The apparel brands and retailers face a greater level of reputation risk of being associated with abusive and dangerous conditions in Bangladesh than ever before." 157 These findings show that MNCs are greatly affected by the the attitudes and opinions of their consumers.

Perhaps the most prominent example of consumer impact on the garment industry is the Nike scandal of the 1990s, discussed briefly in the previous case study. Scholars from University of California, Berkeley found that "international concern over globalization and labor standards increased dramatically" during this time. ${ }^{158}$ Activism took the forms of newspaper campaigns, media exposés, grassroot organizations, and pressure applied on the governments of developing countries. ${ }^{159}$ One strategy that was particularly effective and continues to be completely consumer-driven, is the massive increase in the number of articles published on the topic of labor standards and the condition of workers in the garment industry. Ann Harrison, a professor of economics at UC Berkeley, cites that the number of major newspaper articles that were published "more than tripled" between 1990 and 1996, peaking at over 1,500 articles. ${ }^{160}$ The

155 Mark Anner, Jennifer Bair, and Jeremy Blasi, "Buyer Power, Pricing Practices, and Labor Outcomes in Global Supply Chains". Institute of Behavioral Science. University of Colorado, Boulder. August 2012.

${ }^{156}$ Ann Harrison, and Jason Scorse, "The Nike Effect: Anti-Sweatshop Activists and Labor Market Outcomes in Indonesia," University of California, Berkeley, March 2004, (Accessed June 5, 2013).

157 Steven Greenhouse, "Some Retailers Rethink Role in Bangladesh,” The New York Times, May 1, 2013.

${ }^{158}$ Ann Harrison, and Jason Scorse, "The Nike Effect: Anti-Sweatshop Activists and Labor Market Outcomes in Indonesia," University of California, Berkeley, March 2004, (Accessed June 5, 2013).

${ }^{159}$ Ibid

${ }^{160}$ Ann Harrison, and Jason Scorse, "The Nike Effect: Anti-Sweatshop Activists and Labor Market Outcomes in Indonesia," University of California, Berkeley, March 2004, (Accessed June 5, 2013). 
effects of this period of intense consumer activism produced concrete results at the national and international levels: threats from the United States to increase tariff barriers in Indonesia resulted in "a twenty-five percent increase in real wages for unskilled workers," within this six year period. ${ }^{161}$

It is important to keep in mind that this change instigated by consumers is different from the effects that other actors such as international institutions and MNCs have on the industry. While MNCs can directly determine wages, and international institutions such as the ILO can directly implement conventions and recommendations, consumers can only affect the industry indirectly by using their voice, either through purchasing power or grassroot organization. Harrison reported that consumers in the 1990s used their voices to pressure the U.S. government, which in turn applied pressure on the Indonesian government, "which led to changes in the minimum wage." 162 This should by no means diminish the effects of consumer-driven change, but rather show that this approach tackles the system in a slightly different manner. And, while the "reforms" instigated by Nike in the 1990s have not significantly altered the lives of workers, the uproar that average citizens were able to cause demonstrates the effect that consumers are able to make on the industry. ${ }^{163}$

Another very prominent way that consumers can affect the garment industry is through their purchasing power, or ability to chose what type of products to buy. A TIME Magazine reporter, Brian Walsh, believes that consumers can play a considerable role by carefully choosing which brands to buy, but that it is unlikely that they will be willing to pay more for items produced ethically: "Customers can do their part by putting a little pressure on their favorite brands, though that would require placing as much value on the cost of a life as you might on the cost of a T-shirt." ${ }^{164}$ Bryan Walsh interviewed a 21-year old college student about her willingness to stop buying cheap clothes that have been produced by sweatshop labor. She responded, "it bothers me, but [...] I can't see how I can change anything," continuing that corporations "definitely

161 Ibid

162 Ibid

163 Associated Press, "Worker Rights Violations at Nike Factory in Malaysia," CBC News, August 2008.

${ }^{164}$ Bryan Walsh, "Fast, Cheap, Dead: Shopping and the Bangladesh Factory Collapse," TIME Magazine, April 29, 2013. 
need to improve, but I'll still shop here. It's so cheap."165 Walsh fears that her response is representative of a large portion of apparel consumers, and will reflect a growing generation of apathetic shoppers.

Scholars from Harvard University make the case that consumers actually are interested in buying goods that were produced humanely, and would be willing to pay a higher price for "socially labeled" items. ${ }^{166}$ A different reporter from TIME Magazine supports this theory, saying that there is "evidence that consumers are willing to pay at least a small premium for assurance that their clothing is produced in fair and safe working conditions." ${ }^{167}$ The Harvard scholars believe that if companies improved the working conditions of their employees in developing nations, and advertised it on the product's labels so that consumers were aware, "many consumers would be willing to pay higher prices for such items." ${ }^{68}$ They continue, that if the additional profit earned from the increased price of the product went to cover the "costs associated with raising labor standards," then "everyone would win." These scholars believe that this model has the potential to "improve working conditions without adversely affecting investment and growth in developing countries." ${ }^{69}$ This is a powerful assertion, and one that could have a huge impact on the global commodity chain, if proven effective and implemented. To conclude, the effect that consumers have on the conditions of workers in the garment industry is disputed. Evidence suggests that consumers can make a difference, but only when a large group of people act cohesively. Thus, while consumer-driven change can be tangible, consumers are not the actor with the most influence over the garment industry, and are not the primary culprits for the recent tragedy in Bangladesh.

\section{Implications}

In answer to my research question, workers in the international garment industry have been left extremely vulnerable to exploitation which is a result of

\footnotetext{
165 Ibid

${ }^{166}$ Michael J. Hiscox, and Nicholas F. B. Smyth, "Is There Consumer Demand for Improved Labor Standards?," Department of Government, Harvard University, 2006.

167 Pietra Rivoli, "Viewpoint on Bangladesh Disaster: Its Not All About the West," TIME Magazine. May 2, 2013.

${ }^{168}$ Pietra Rivoli, "Viewpoint on Bangladesh Disaster: Its Not All About the West," TIME Magazine. May 2, 2013.

${ }^{169}$ Ibid
} 
multiple actors falling short of their duties. This paper explored the roles that three different actors play in the lives of garment workers, and reveals that each has the capability to affect labor conditions in its own unique way. However, my research findings suggest that multinational corporations are able to exert more influence over wages, enforcement, and working conditions, than the other levels of the global supply chain. The key to improving conditions for workers in this industry, is understanding how each of these actors act and interact, and knowing the weight that each can pull in the international arena. The solution to the problem of worker exploitation will involve all three actors to some degree, as well as some other actors that were not discussed, such as NGOs and local and national governments. But, the largest takeaway from this paper is that while consumers are decidedly not using their purchasing power enough to effectively choose which companies to support, and while the ILO may not be aggressive enough on the enforcement of its conventions abroad, it is the multinational corporations who are markedly inhibiting the conditions of workers from improving by intentionally keeping wages and prices irreconcilably low. Thus, it is imperative for all actors to come together to tackle the issue of basic human rights, as each is an integral piece to this complex puzzle; however, it is the multinational corporations that must make the most significant changes in their practices and policies in order for palpable and lasting improvements to be made in the lives of garment workers worldwide. 


\section{BIBLIOGRAPHY}

A. Chandler Jr., and B. Mazlish, "Leviathans: Multinational Corporations and the New Global History,” Cambridge: Cambridge University Press. 2005.

Alexander Anievas, "Marxism and World Politics: Contesting Global Capitalism," London: Routledge, 2010.

Alexandre Kirchberger, "Marx, Ideology, and International Relations," University of Sussex, http://www.sussex.ac.uk/cspt/documents/issue6-3.pdf (Accessed June 4, 2013).

Ann Harrison, and Jason Scorse, "The Nike Effect: Anti-Sweatshop Activists and Labor Market Outcomes in Indonesia," University of California, Berkeley, March 2004, www.econ.yale.edu/seminars/develop/tdw04/harrison-040322.pdf. (Accessed June 5, 2013).

Associated Press, "Bangladesh Probe Faults Swampy Land, Poor Building Materials, Heavy Equipment for Collapse,” The Washington Post, May 22, 2013.

Associated Press, "Worker Rights Violations at Nike Factory in Malaysia," CBC News, August 2008, http://www.cbc.ca/news/world/story/2008/08/01/nike-violations. html.

Bill Dunn, “Global Political Economy: A Marxist Critique” London: Pluto, 2009.

Bryan Walsh, "Fast, Cheap, Dead: Shopping and the Bangladesh Factory Collapse," TIME Magazine, April 29, 2013, http://science.time.com/2013/04/29/ fast-cheap-dead-shopping-and-the-bangladesh-factory-collapse/.

B.S. Chimni, "Marxism and International Law: A Contemporary Analysis," Center for Studies in Diplomacy, International Law, and Economics. School of International Studies Jawaharlal Nehru University, New Delhi. csssjnu.tripod.com/marx.html (Accessed June 8, 2013).

D. Rodrik, "Has Globalization Gone Too Far," Washington: Institution for International Economics, 1997. 
David McLellan and Sidney Hook, "Marx: The First Hundred Years; Marxism and Beyond," Foreign Affairs, 1983. http:/www.foreignaffairs.com/articles/37487/ john-c-campbell/marx-the-first-hundred-years-marxism-and-beyond.

Dexter Roberts and Pete Engardio, "Secrets, Lies, and Sweatshops," Bloomberg Businessweek Magazine, November 26, 2006, http://www.businessweek.com/ stories/2006-11-26/secrets-lies-and-sweatshops.

Eugenia Levenson, “Citizen Nike," CNN Money, November 17, 2013, http://money. cnn.com/2008/11/17/news/companies/levenson_nike.fortune/.

G. Gereffi, "International Trade and Industrial Upgrading in the Apparel Commodity Chain,” Journal of International Economics 1999.

Gareth Dale, "Marxism,” Oxford Bibliographies, March 2, 2011.

International Labor Organization, "Applying and promoting international labor standards," 2013, http:/www.ilo.org/global/standards/applying-and-promotinginternational-labour-standards/lang--en/index.htm (Accessed June 8, 2013).

Hector Figueroa, "In the Name of Fashion: Exploitation in the Garment Industry," CorpWatch, January 1, 1996. http://www.corpwatch.org/article.php?id=3034 (Accessed May 26, 2013).

“ILO/IFC Partnership,” Better Work, International Labor Office, 2012, http:// betterwork.org/global/?page_id=304

International Labor Organization, "Applying and promoting international labor standards," 2013, http://www.ilo.org/global/standards/applying-and-promotinginternational-labour-standards/lang--en/index.htm (Accessed June 8, 2013).

International Labor Organization, "Conventions and Recommendations," 2013, http:// www.ilo.org/global/standards/introduction-to-international-labour-standards/ conventions-and-recommendations/lang--en/index.htm (Accessed June 8, 2013).

Janelle McCalla, “Global Reputation,”https://sites.google.com/a/email.vccs.edu/ bus100jmccalla/home/global-reputation-2 (Accessed May 28, 2013).

Jeffrey M. Jones, “Americans Shift to More Positive View of Foreign Trade," Public Opinion Polling, Gallup Economy, February 28, 2013. (Accessed May 20, 2013). 
Julfikar Ali Manik and Jim Yardley, "Scores Dead in Bangladesh Building Collapse," The New York Times, April 24, 2013, sec. World / Asia Pacific.

Kimberly Ann Elliot, “The ILO and Enforcement of Core Labor Standards,” International Economy Policy Briefs, Institute for International Economics, July 2000 http:// www.iie.com/publications/pb/pb00-6.pdf (Accessed June 10, 2013).

Lora Jo Foo and Julie A. Su, "Let the Sweatshop Reform Law Work," The Los Angeles Times, April 7, 2000. http://articles.latimes.com/2000/apr/07/local/me-16873.

Mark Anner, Jennifer Bair, and Jeremy Blasi, "Buyer Power, Pricing Practices, and Labor Outcomes in Global Supply Chains”. Institute of Behavioral Science. University of Colorado, Boulder. August, 2012.

"Marxism: International Relations Theory in Brief," Bukisa, August 15, 2010. http:// www.bukisa.com/articles/335694_marxism-international-relations-theory-in-brief.

Michael J. Hiscox, and Nicholas F. B. Smyth, "Is There Consumer Demand for Improved Labor Standards?,” Department of Government, Harvard University, 2006.

Nazia Habib-Mintz, "Multinational Corporations' Role in Improving Labour Standards in Developing Countries,"Journal of International Business and Economy, April 4, 2009.

Pew Research Center, "Confidence in Obama Lifts U.S. Image Around the World," Public Opinion Polling, Pew Global Attitudes Project, July 23, 2009. (Accessed May 22, 2013).

Pew Research Center, "Economies of Emerging Markets Better Rated During Difficult Times," Public Opinion Polling, Pew Global Attitudes Project, May 23, 2013. (Accessed May 23, 2013).

Pietra Rivoli, "Viewpoint on Bangladesh Disaster: Its Not All About the West," TIME Magazine. May 2, 2013. http://ideas.time.com/2013/05/02/ viewpoint-on-bangladesh-disaster-its-not-all-about-the-west/.

Q. Tahmina, "Labour-Bangladesh: Garment Exports Thrive on Dirt," Inter Press Service News Agency. April, 2007, ipsnews.net/news.asp?idnews=34936 (Accessed June 6, 2013). 
Steve Boggan, "Nike Admits to Mistakes Over Child Labor," The Independent UK, October 20, 2001http://www.commondreams.org/headlines01/1020-01.htm.

Steven Greenhouse, "Some Retailers Rethink Role in Bangladesh," The New York Times, May 1, 2013.

“Sweatshops,” International Labor Rights Forum. 2012. http://www.laborrights.org/ creating-a-sweatfree-world/sweatshops (Accessed May 28, 2013).

“The ILO to the Rescue?," Institute for International Economics, pp.93-109, http://www. piie.com/publications/chapters_preview/338/5iie3322.pdf (Accessed June 7, 2013).

“Wal-Mart Campaign,” International Labor Rights Forum, 2012, http://www.laborrights. org/creating-a-sweatfree-world/wal-mart-campaign (Accessed May 22, 2013).

William H. Cooper, "The Future of U.S. Trade Policy: An Analysis of Issues and Options for the 112th Congress," CRS Report R41145, Washington DC, Congressional Research Service, January 4, 2011. http:/www.fas.org/sgp/crs/row/R41145.pdf (Accessed June 1, 2013).

William J. Clinton, "Remarks Announcing Measures to Improve Working Conditions in the Apparel Industry and an Exchange with Reporters," (speech, U.S. Congress, Washington DC, August 2, 1996), The American Presidency Project, www. presidency.ucsb.edu/ws/index.php?pid=53144\&st $=\& s t 1=$.

World Trade Organization, “Core Labor Standards," Singapore Ministerial Declaration, April 2007, www.jus.uio.no/lm/wto.ministerial.declaration.singapore.1996/4.html. 